\title{
Influence of Land Degradation on the Local Rate of Dust Fallout in Kuwait
}

\author{
Jasem M. Al-Awadhi ${ }^{*}$, Ali M. Al-Dousari², Fikry I. Khalaf ${ }^{1}$ \\ ${ }^{1}$ Department of Earth and Environmental Sciences, Faculty of Science, Kuwait University, Safat, Kuwait \\ ${ }^{2}$ Department of Coastal and Air Pollution Department, Kuwait Institute for Scientific Research, Safat, Kuwait \\ Email: ${ }^{*}$ jawadhi@kuc01.kuniv.edu.kw, ${ }^{*}$ jawadhi1@live.com
}

Received 23 May 2014; revised 18 June 2014; accepted 18 July 2014

Copyright @ 2014 by authors and Scientific Research Publishing Inc.

This work is licensed under the Creative Commons Attribution International License (CC BY). http://creativecommons.org/licenses/by/4.0/

c) (i) Open Access

\section{Abstract}

The rate of dust fallout was monitored during a period from August 2009 to July 2011 in protected (closed) and non-protected/open (unenclosed) areas in the northern desert of Kuwait. The dust fallout rates on degraded and protected sites were on average 18.8 and $44.1 \mathrm{~g} \cdot \mathrm{m}^{-2} \cdot \mathrm{month}^{-1}$, respectively. Higher rate of dust fallout in protected area may be attributed to biologic factors that are responsible for relative abundance of fine-grained sediment accumulations (Mostly silty sand). Wind deflation of fine grained sediment fractions and development of coarse-grained surface lag deposits in degraded area may be accountable for the reduction of its potentiality for suspended dust. The study indicates the importance of the vegetation cover in regulating sediment availability for atmospheric dust emission.

\section{Keywords}

\section{Dust Fallout, Vegetation Cover, Degraded Area, Wind Deflation}

\section{Introduction}

Dust storms are common phenomena in many parts of the world, especially in arid and semi-arid regions. The Arabian Peninsula is one of the five major regions where dust originates [1]. Khalaf and Al-Hashash [2] reported that dust storms were usually caused by the action of strong persistent winds on dry, fine-grained, and loose soil. During the occurrence of dust storms, a complete aeolian sedimentary cycle takes place, namely erosion, transportation and deposition. The rate of dust fallout in the Arabian Gulf region varies from $191 \mathrm{~g} \cdot \mathrm{m}^{-2} \cdot \mathrm{month}^{-1}$ in Kuwait [2] to $392 \mathrm{~g} \cdot \mathrm{m}^{-2} \cdot \mathrm{yr}^{-1}$ in Riyadh, Saudi Arabia [3]. Al-Dousari and Al-Awadhi [4] indicated that the average annual dust fallout rate for the period from $1^{\text {st }}$ November 2006 to $31^{\text {st }}$ December 2007, in Kuwait reached

"Corresponding author. 
$112 \mathrm{~g} \cdot \mathrm{m}^{-2}$

Many studies have been focused on dust entrainment, transport, deposition, and accumulation in arid and semi-arid environments where the potential for aeolian entrainment and suspension of fine grained sediment is enhanced by low moisture availability and sparse vegetation cover [5]. However, entrainment and deposition of locally-derived dust in these environments are mostly controlled by prevailing magnitude of aridity, wind climate and availability of source sediments [6] [7]. Aeolian dust fallout influences surficial and ecological processes in desert regions, where it plays important roles in soil formation, soil hydrology, distribution of biologic soil crusts, and nutrient status (e.g., [8]-[19]). Suspended dust is derived from anthropogenic, natural and biogenic sources [20]. Windblown dust from natural sources is estimated to account for $89 \%$ of the global aerosol load [21]. The nature of surface cover and the magnitude of anthropogenic activities may play a significant role in the occurrence of suspended dust and eventually the rate of dust fallout.

The present paper aims at the assessment of the impact of land degradation, which particularly results from anthropogenic activities, on the rate of dust fallout in the desert of Kuwait. The granulometric characteristics of the dust fallout are also discussed.

\section{Environment of Kuwait}

The State of Kuwait is situated at the northwestern corner of the Arabian Gulf, and it covers an area of 17,818 $\mathrm{km}^{2}$ (Figure 1). The surface of Kuwait is carved in the Mio-Pleistocene calcretic formation during early Holocene pluvial periods. The carved depressions and water courses are filled by the fluvial and alluvial sediments.
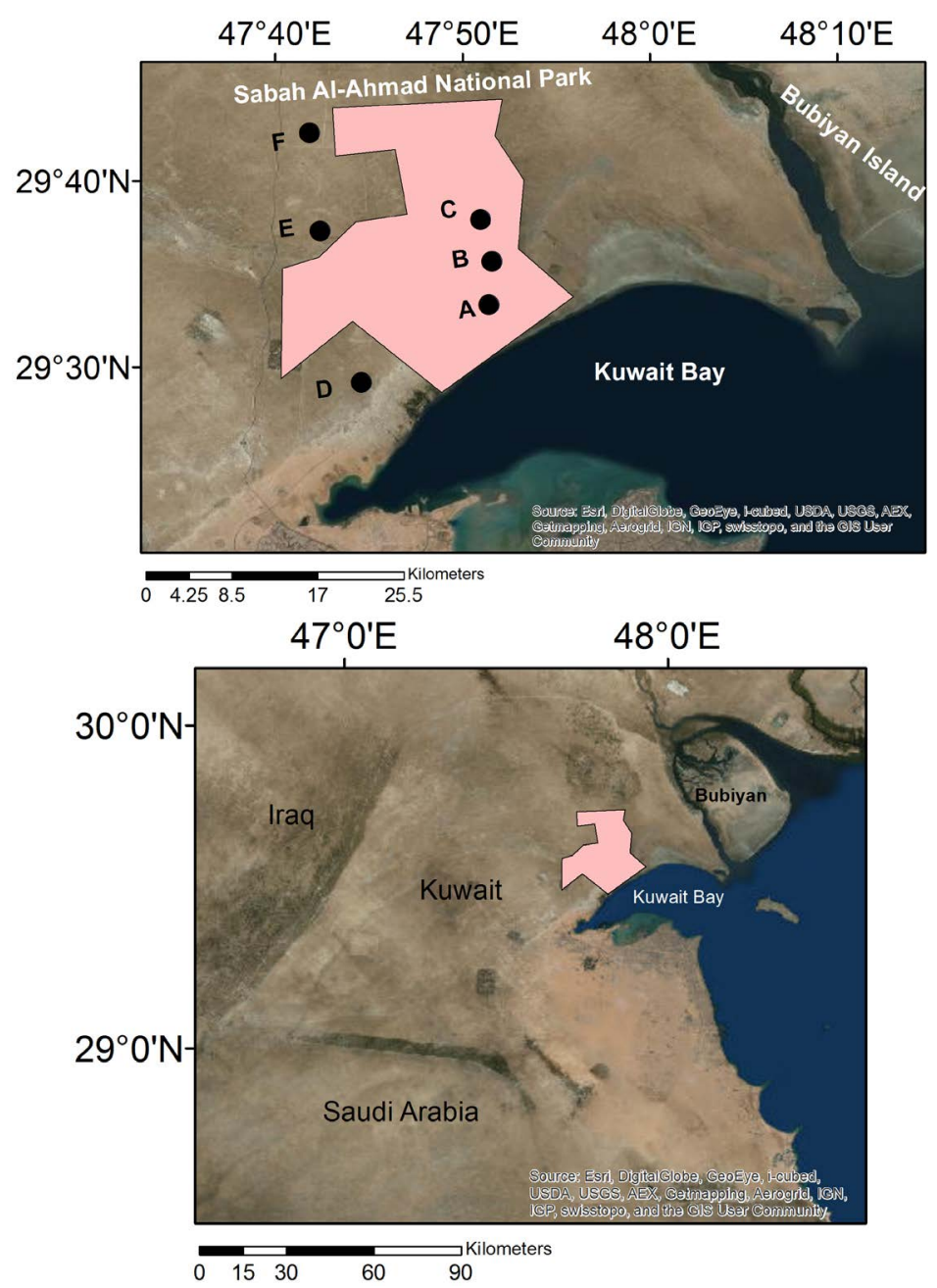

Figure 1. The study area and dust collector locations (A - F). 
By the advent of aridity, aeolian processes started to act on these fluvial sediments as the present-day aeolian landforms were developed. These landforms can be grouped into erosional and depositional landforms [22]. Erosional landforms are represented by 1) calcretic and gypcretic rock exposures, which occur as flat terrain and small humps and some are yardangs; 2) desert pavement represented by pebbly lag, granule lag, and mixed lag; and 3) granule ripples. Depositional landforms include 1) sand dunes, 2) nabkhas and sand drifts, 3) sand sheets, and 4) anthropogenic-related sand accumulations.

Halwagy and Halwagy [23] and Halwagy et al. [24] recognized three distinct vegetation communities within Kuwait, namely, 1) a dwarf shrub community of Rhanterium epapposum dominated the southern half of the country; 2) Cyperus conglomeratus which replaces $R$. epapposum as the key perennial species, probably as a result of overgrazing; and 3) the chenopod Haloxylon salicornicum community that is prevalent in the northern Kuwait

Statistical summary of meteorological data for the period 1957-2008 (Kuwait International Airport) indicates that the climate in Kuwait is arid with mean annual rainfall of $119 \mathrm{~mm}$, while mean annual potential evapotranspiration exceeds $2270 \mathrm{~mm}$. Average air temperature is $37^{\circ} \mathrm{C}$ and $17^{\circ} \mathrm{C}$ in summer (May - September) and winter (October - April), respectively. The wind blows dominantly from the northwest and, to a lesser extent, the southeast. Wind direction in Kuwait is fairly consistent; about $75 \%$ of the winds blow from the west, northwest, and north. The average monthly wind speed ranges from 8.7 knots (in January and December) to 11.2 knots (in June and July) and $12 \%$ of the year has a calm wind [25].

Sand and dust storms are frequent during the summer period (Figure 2). There are two broad categories of dust storms: those associated with winds and those that rely on the heat transfer from the soil surface to generate an updraft. Also, dust devils, locally called "Toz", often occur during the daytime without any winds because of the sudden raising of heated air currents. It is believed that this kind of dust bowl moves over a small area and usually disappears after a while. It is strongly believed that sand-dust storms in Kuwait are closely related to uncontrolled human activities such as quarrying, desert camping and off-road driving in open desert areas.

Several land-use types are recognized within Kuwait territory. These can be grouped into six main land use types, namely, open rangeland, oil fields, protected areas, agricultural areas, military areas, and urban areas. Open rangeland and protected area, which are the subject of the present study, constitutes about $75.12 \%$ and $1.93 \%$, respectively, of Kuwait's terrestrial area [26].

In recent decades, Kuwait has suffered severe land degradation, as noted by several authors (e.g., [25] [27]-[39]). The main causes of this problem can be attributed principally to overgrazing, but also to recreational activities such as off-road driving and camping, as well as industrial practices, particularly quarrying [25] and [27]. In addition, serious damage was inflicted on the natural environment during the Iraqi occupation in 1990

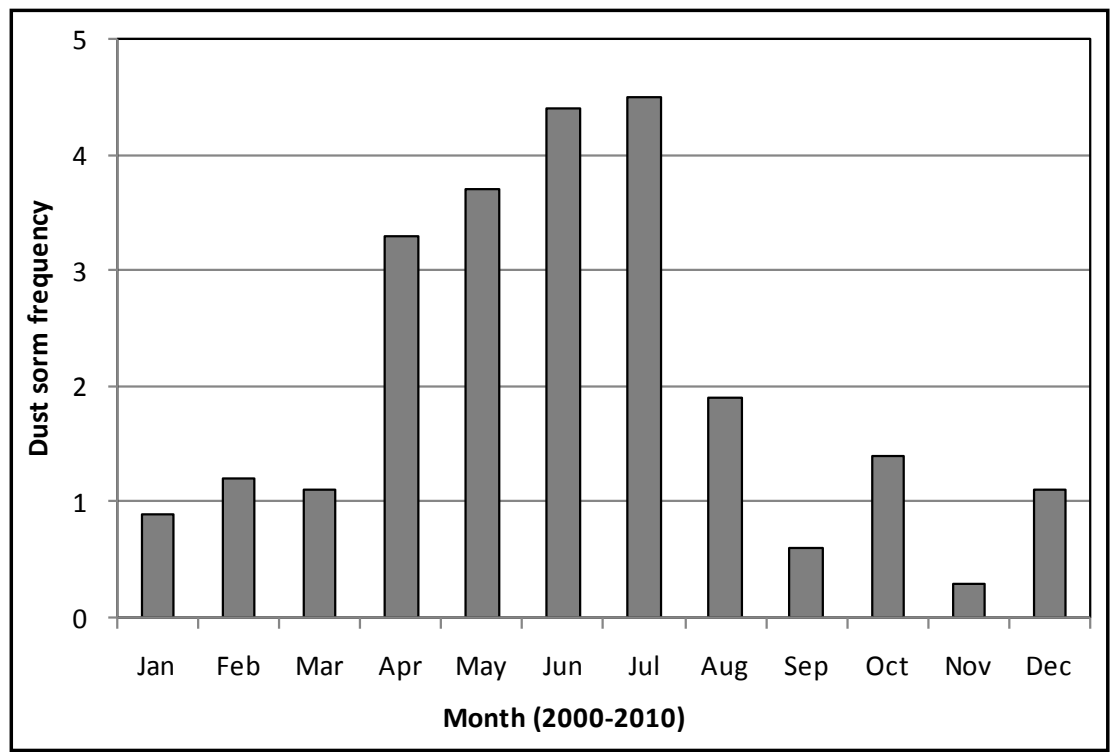

Figure 2. The monthly average number for dust storm days in Kuwait (2000-2010) (after Al-Dousari and Al-Awadhi [4]). 
and the hostilities associated with the liberation of the country during the Gulf War [34] and [40]. The study of Misak et al. [33] indicated that at least 76\% of the desert ecosystem of Kuwait suffers different degrees of land degradation; the map of land degradation hazard in Kuwait, produced by Al-Awadhi [38], indicates very high, high, moderate and low degrees of land degradation constitutes about $15 \%, 36.6 \%$, 35\%, and $13.4 \%$, respectively.

\section{Study Region}

The study region covers protected and open areas. The protected area the Sabah Al-Ahmad Natural Reserve (see Figure 1) was inaugurated on $3^{\text {rd }}$ March 2004. It is designated to be the largest natural park in the country with a total area of $330 \mathrm{~km}^{2}$ and boundary length of $99.13 \mathrm{~km}$. It comprises diverse landscape features and plant and animal life forms from both coastal and terrestrial ecosystems. Rhanterium epapposum (60\%), Haloxylon salicornicum (30\%), Nitraria retusa and Zygophyllum qatarense (10\%) are the dominant plant communities in the reserve [37]. The protection of this reserve from all anthropogenic activities has resulted in a sequence of ecological changes leading to self rehabilitation of natural vegetation. This is mostly manifested by significant increase in its vegetation cover (Figure 3(a)). Abundance and flourishing of vegetation has changed the aeolian processes within this reserve from erosional to depositional. These conditions have led to the development of growing of nabkhas (accumulation of sediments around shrubs). One of the major depressions in Kuwait (Umm El Rimmam depression) is also located at the northwest of this reserve. This depression is mostly covered by fine-grained sediments [41].

The open area is dominated by rangeland which is used primarily for anthropogenic activities including grazing and recreational activities such as spring camping and off-road vehicle traffic. It is characterized by thin and poor vegetation cover (Figure 3(b)). The latter is represented by scattered shrubs and degraded (eroded) nabkhas. Pebbly and granuley lag covers most of the open area (Figure 4(a)). The spring camping and off-road traffic activities can be seen as scars across the desert as no particular access roads are used (Figure 4(b)). In the vicinity of the study area, the southern open areas exert highest rate of off-road traffic tracks (more than 2.6 $\mathrm{km} \cdot \mathrm{km}^{-2}$ ) while the northern areas exert a less rate $\left(1.3 \mathrm{~km} \cdot \mathrm{km}^{-2}\right)$.

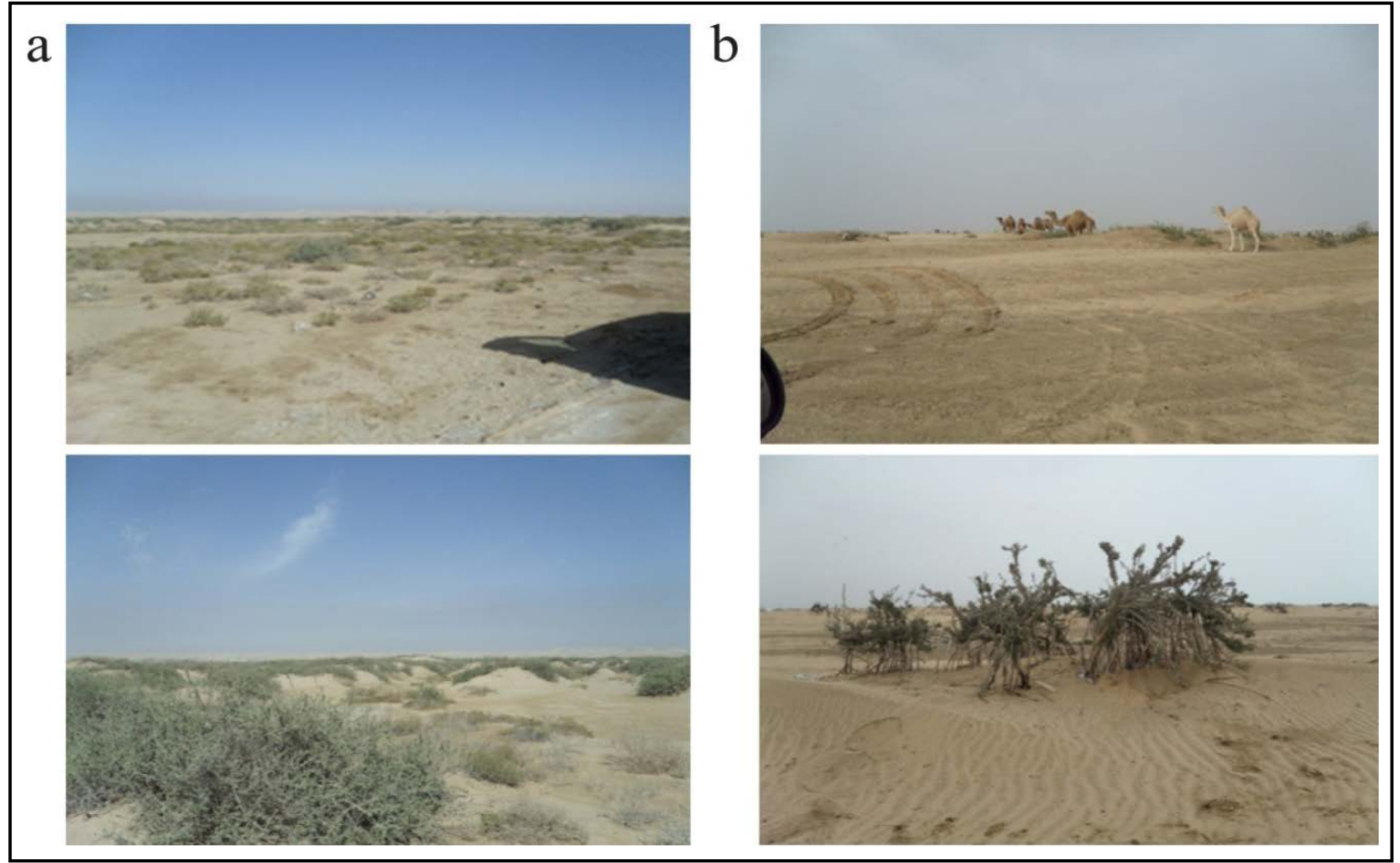

Figure 3. Vegetation coverage and nabkha status in the study area; (a) inside Sabah Al-Ahmad Reserve, (b) outside the Reserve (open area). 


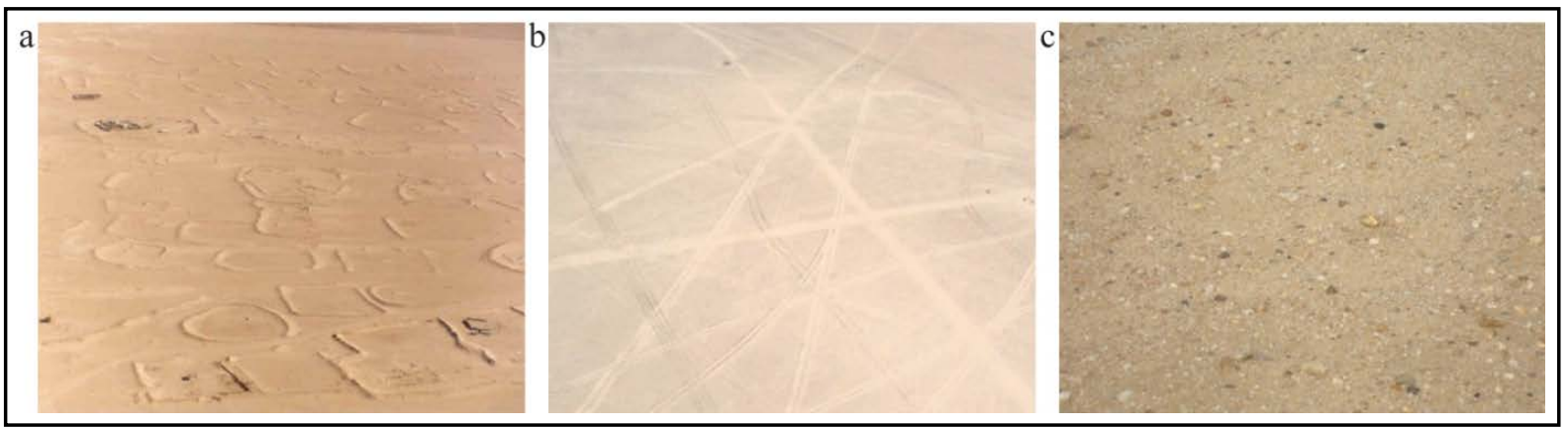

Figure 4. Wind deflation and exposing coarse material (c) due to spring camping (a) and off-road activities in the open area (b) at location D (see Figure 1).

Spot imageries of March 2010 were analyzed by Kuwait Environment Public Authority (KEPA) to map the vegetation cover in the study area and its surrounding. Various image processing techniques such as layer stacking, image sub-setting, spectral stretching, spatial masking, overly analysis, and Normalized Difference Vegetation Index (NDVI), were utilized to map and analyze the image for vegetation cover in the area (Figure 5). Table 1 indicates that the vegetation density in the protected sites is exceeds that of the non-protected sites by about $83 \%$ in average.

\section{Materials and Methods}

Six dust fallout collectors were installed at $240 \mathrm{~cm}$ above ground surface in the study area, three in the open (non-protected) area and three in the protected area (Sabah Al Ahmad nature reserve) (see Figure 1). In each area the samplers are arranged in such a manner that one at the upwind (locations $\mathrm{C}$ and $\mathrm{F}$ ) and one at the downwind (locations A and D) and the third is in between (locations B and E). The dust fallout collector consists of a stainless steel bucket $15 \mathrm{~cm}$ in diameter [4] and [42]. Sampling sites were chosen to be away from any infrastructure and to represent the prevailing environmental conditions in the open and protected areas. The fallen dust rates were monitored on monthly basis for the period from $1^{\text {st }}$ August 2010 to $31^{\text {st }}$ July 2011. The collected dust fallout samples were carefully washed into sample containers. The samples were dried and weighed. The dust deposition rate was first calculated as the ratio between the sample weight collected during each sampling period and the area of the dust-trap opening $\left(\mathrm{A}=\pi \mathrm{r}^{2}\right.$, where $\mathrm{r}$ is top radius of the bucket; $7.5 \mathrm{~cm}$ [42]) and then converted to $\mathrm{g} \cdot \mathrm{m}^{-2}$. The particle size distribution was determined using standard sieve analysis and Centrifugal Particle Analyzer (Shumadzu, SA-CP3). The grain size parameters were calculated according to Folk [43].

\section{Results}

\subsection{Dust Fallout Rates}

The average monthly rate of dust fallout varied from 3.2 to $220 \mathrm{~g} \cdot \mathrm{m}^{-2}$. Significant spatial and temporal variations in the monthly rate of dust fall out were recognized. The highest rates were recorded in February, March and April, where the monthly averages within the six sampling sites are 53.1, 86.0 and $45.1 \mathrm{~g} \cdot \mathrm{m}^{-2}$, respectively (Figure 6). March witnessed the highest rate of dust fallout within both protected and open areas, 111.6 and $60.3 \mathrm{~g} \cdot \mathrm{m}^{-2}$, respectively. It was also noticed that the monthly average of dust fallout rate is relatively high within the middle of the protected area $\left(74.1 \mathrm{~g} \cdot \mathrm{m}^{-2}\right)$ while in the open area the highest rate recorded at the downwind site $\left(21.4 \mathrm{~g} \cdot \mathrm{m}^{-2}\right)$.

Surprisingly, the average monthly rates of dust fallout within the protected area were higher than that within the open area. They range between 3.2 and $220 \mathrm{~g} \cdot \mathrm{m}^{-2}$ within an average of $41.6 \mathrm{~g} \cdot \mathrm{m}^{-2}$ in the protected area and between 3.3 and $71.7 \mathrm{~g} \cdot \mathrm{m}^{-2}$ within an average of $18.0 \mathrm{~g} \cdot \mathrm{m}^{-2}$ in the open area.

The spatial pattern of dust accumulation along the transect in the open area indicates a generally consistent trend of decreasing dust fallout rate away from the downwind site (site F). At the northwestern transect the accumulation rate decreases by $40 \%$ in average over a transect distance (sites: F-E-D), indicating increase dissipation of the sediment carrying capacity of the prevailing wind (NW) as it enters the open area. The high rate of dust fallout rate at the southeastern transect (site D) is mainly due to intensive overgrazing of rangeland by 
Table 1. Vegetation coverage percentage inside and outside the Sabah Al-Ahmed Natural Reserve.

\begin{tabular}{|c|c|c|c|c|c|}
\hline Vegetation cover (\%) & Site 1 & Site 2 & Site 3 & Site 4 & Site 5 \\
\hline Outside Reserve & 6 & 4 & 14 & 6 & 0 \\
\hline Inside Reserve & 20 & 30 & 51 & 45 & 51 \\
\hline Difference (\%) (Times) & $\begin{array}{c}3.3 \\
70\end{array}$ & $\begin{array}{c}7.5 \\
86.6\end{array}$ & $\begin{array}{c}3.6 \\
72.5\end{array}$ & $\begin{array}{c}7.5 \\
86.6\end{array}$ & 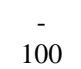 \\
\hline
\end{tabular}

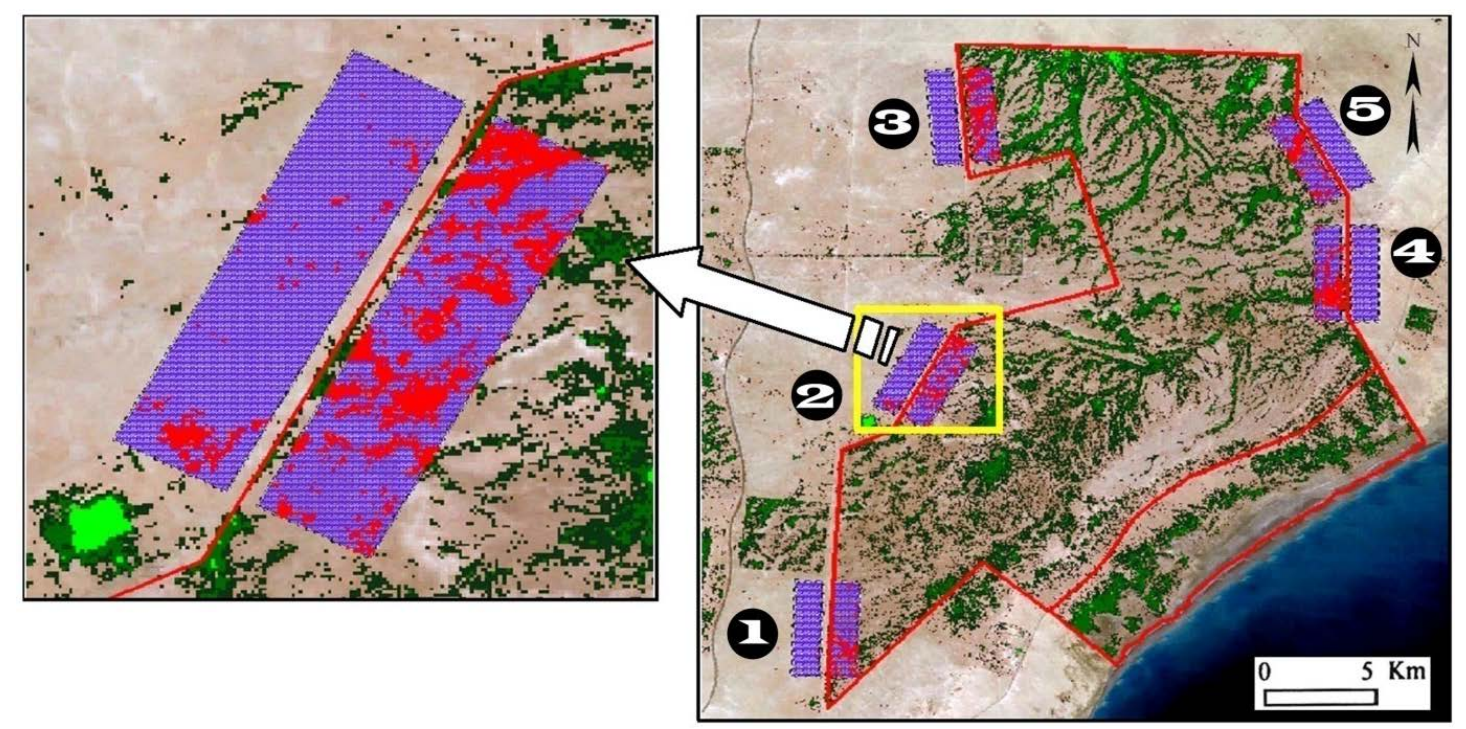

Figure 5. Overlay output and location of the straps of interest pairs inside and outside the Sabah Al-Ahmad Natural Reserve. Five zones ( 1 to 5 ) along the east fence and west fence of the reserve, equal, adjacent and parallel pairs of straps (1000 m wide $\times 4000 \mathrm{~m}$ long) were selected for vegetation cover comparison purpose.

livestock and spring camping and recreation in the vicinity of this site during October to March and exerting highest rate of off-road intensity; during this period the average dust fallout rate in site D where 1.2 times higher than in site $\mathrm{E}$ and 1.4 times higher than in site F.

\subsection{Particle Size Distribution of Dust Fallout}

Figure 7 presents the average grain size distribution of the collected dust fallout samples. No significant variation was recognized in the grain size characteristics of the collected dust fallout. It slightly varies between sandy silt and silty sand. Dust fallout within protected area is mostly silty sand; it is formed of $44.2 \%$ sand, $53.8 \%$ silt and $2 \%$ clay in average, while that of open area is more sandy, it consists of $49.1 \%$ sand, $48.3 \%$ silt and $2.6 \%$ clay in average. Fine and very fine sand are the most dominant size classes within the sand population while coarse and medium silt are the most frequent silt size classes.

Grain size distribution of the dust fallout in both the protected and open areas is bimodal. The primary mode is very fine sand $(0.125-0.063 \mathrm{~mm})$ and constitutes about $20 \%$ in average, while the secondary mode is coarse silt $(0.02-0.05 \mathrm{~mm})$ and constitutes about $17 \%$ in average.

\section{Discussions}

Variations in the rate of dust fallout and its grain size characteristics may be attributed to the variability in the magnitude of land degradation within the study area. Significant variations in the vegetation cover and associated landforms, which may be considered as direct indicators for land degradation, are recognized. The protected area is characterized by the relative abundance of vegetation as well as depressions and wadi fill deposits which are mostly muddy sand and derived by surface runoff washout. The reserve area is characterized by abundant occurrence of nabkhas developed around Nitraria retusa shrubs. A shrub not only dissipates much of wind energy at its base, but creates an increasingly wide "wake zone” downwind as it gains height. Immediate 
consequences of this wake occurring within the sheltering effect zone are an increase in the turbulence effects [44], thus decreasing the threshold shear velocity for dust suspension by wind. On the other hand, open area is mostly a deflation plain with very thin scattered vegetation covers (shrubs), and their sediments have been considerably deflated and present as rippled coarse sand and granules. Al-Awadhi [39] found that the total average percentages of course grain size in disturbed (open area) and off-road soils in the study area, compared to undisturbed soils (protected area), are increased by $51 \%$ and $10.3 \%$, respectively. While the total average percentages of clay-size in the disturbed and off-road soils are decreased by $22 \%$ and $31 \%$, respectively. This means that the aeolian sand deposits are more subjected to deflation processes in unprotected areas than that in protected ones.

The active deflation in open area is therefore responsible for the development of a course sand and granule lag cover (desert pavement). Such lag armors the underlying loose material and shelters it from deflation. Intensive and extensive off-road of heavy machinery vehicle movements are even more responsible to scrape the surface layers and develop lag gravel. This not only produces surface erosion, but it also alters the micro-relief, disturb the surface and damage the vegetation cover. Thus, the relative abundance of dust fallout within the protected area may be attributed to local conditions which are characterized by frequent occurrence of the silty sand around the shrubs (nabkhas) and wadi fill deposits, and the deflational nature of the open area may also be responsible for the decrease in the generated suspended dust and eventually reduction in the rate of dust fallout. However, it should be noted that this is not the case in the event of sever regional dust storms that are usually caused by high speed winds in gust conditions. Intensive anthropogenic activities, mainly from overgrazing of rangeland by livestock, spring camping and off-road traffic activities, may have led to significant loss of finer particles leaving behind the coarser material [45], particularly at the southeastern site of the open area (location D).

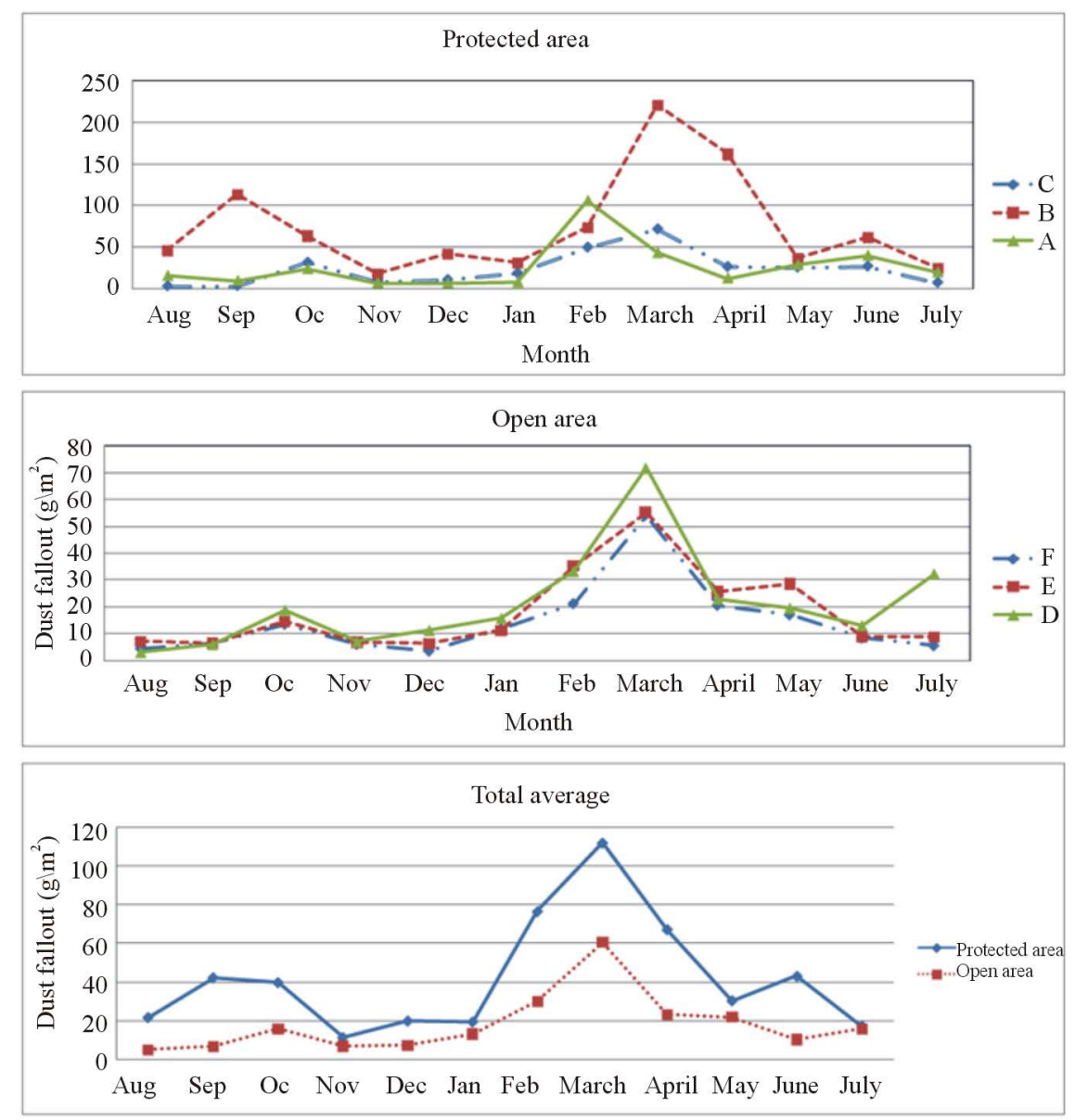

Figure 6. Average monthly variations of dust fallout rates in the six locations. 

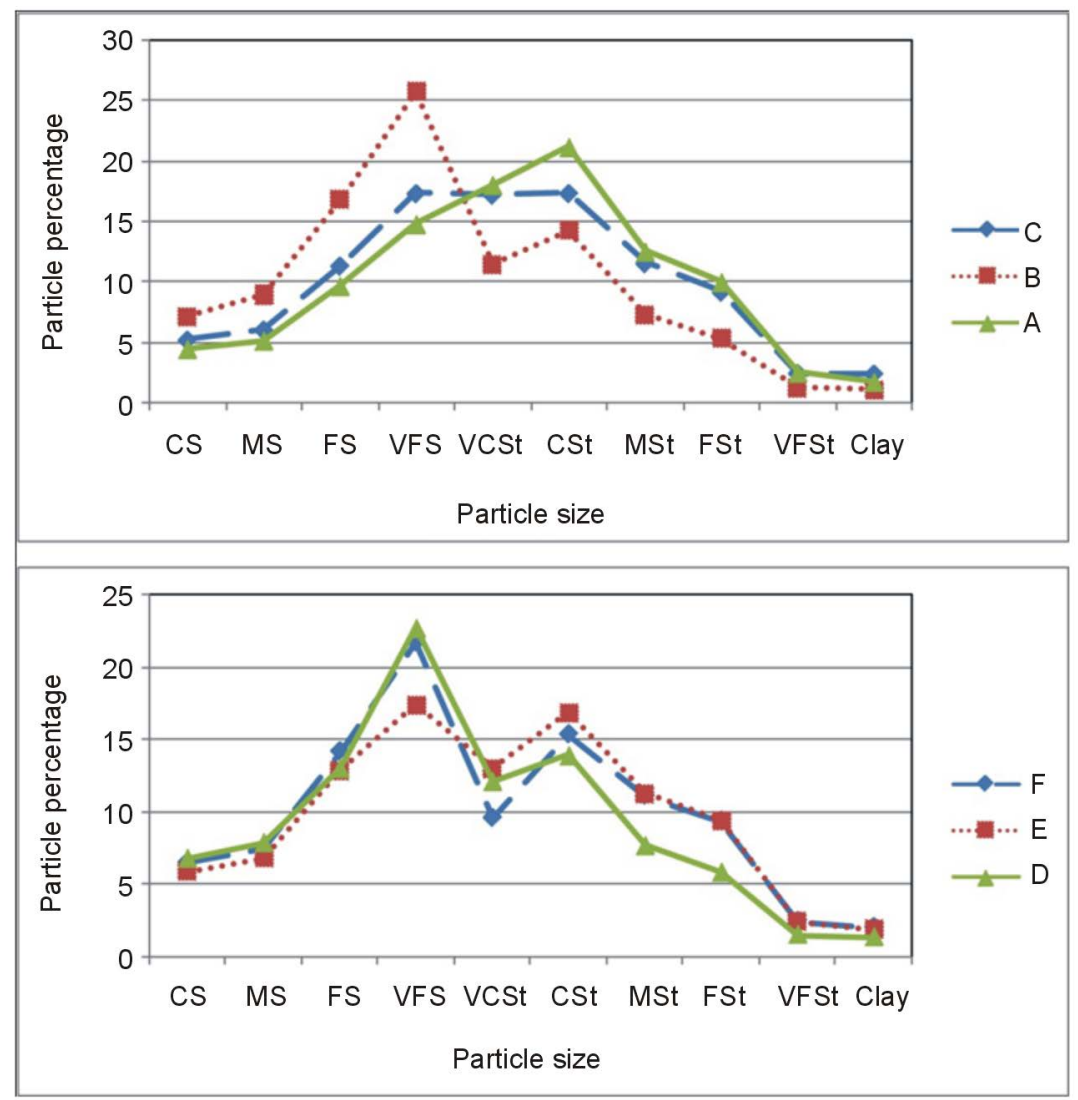

Figure 7. Average grain size percentages of dust fallout in the reserve (a) and outside the reserve (b).

The average ratio of very fine sand to silt is less than 1.0, indicating that most of the dust is comprised of silt sized grains. Nevertheless, the proportion of sand-sized particles present in the samples was unexpectedly high (34\% - 59\%), suggesting that wind speed is often sufficient to entrain sand grains into short-term suspension. Clay content is relatively low, presumably because the wind erosion in the area is too active resulting in substantial deposition of coarser material over the bed of the study area; i.e., the sediment source is deficient in clay-sized particles.

\section{Conclusion}

Spatio-temporal patterns of dust fallout over a 24-month period in the State of Kuwait highlighted the roles of the vegetation cover as an environmental agent in regulating sediment availability for dust emission. Field results showed that rate of dust fallout might be influenced by land degradation, where protected area was relatively rich in fine-grained particles which provided an effective source for suspended dust than in degraded areas. Rates of dust deposition in protected area were greater by a factor of 2.3 on average than in adjacent degraded open areas. This study also demonstrated that increased vegetation coverage by $83 \%$ considerably increased dust accumulation from 216 to $500 \mathrm{~g} \cdot \mathrm{m}^{-2} \cdot \mathrm{yr}^{-1}$.

\section{Acknowledgments}

This work was supported by Kuwait University Research Grant No. [SE01/11].

\section{References}

[1] Idso, S.B. (1976) Dust Storms. Scientific American, 235, 108-114.

http://dx.doi.org/10.1038/scientificamerican1076-108 
[2] Khalaf, F. and Al-Hashash, M. (1983) Aeolian Sedimentation in the North-Western Part of the Arabian Gulf. Journal of Arid Environments, 6, 319-332.

[3] Al-Tayeb, N.T. and Jarrar, B.M. (1993) Dustfall in the City of Riyadh. Proceedings of the Industrial Air Pollution Symposium, Riyadh, 15-17 November 1993, 66-74.

[4] Al-Dousari, A.M. and Al-Awadhi, J.M. (2012) Dust Fallout in Northern Kuwait, Major Sources and Characteristics. Kuwait Journal of Science, 39, 171-187.

[5] Goudie, A.S. and Middleton, N.J. (2006) Desert Dust in the Global System. Springer, New York.

[6] Nickling, W.G. (1978) Aeolian Sediment Transport during Dust Storms: Silms River Valley Yakon Territory. Canadian Journal of Earth Science, 15, 1069-1084. http://dx.doi.org/10.1139/e78-114

[7] Walker, D.A. and Everett, K.R. (1991) Loess Ecosystem of Northern Alaska: Regional Gradient and Top Sequence at Prudhoe Bay. Ecological Monographs, 61, 437-464. http://dx.doi.org/10.2307/2937050

[8] Yaalon, D.H. and Ganor, E. (1973) The Influence of Dust on Soils during the Quaternary. Soil Science, 116, $146-155$. http://dx.doi.org/10.1097/00010694-197309000-00003

[9] Wells, S.G., Dohrenwend, J.C., McFadden, L.D., Turrin, B.D. and Mahrer, K.D. (1985) Late Cenozoic Landscape Evolution on Lava Flow Surfaces of the Cima Volcanic Field, Mojave Desert, California. Geological Society of America Bulletin, 96, 1518-1529. http://dx.doi.org/10.1130/0016-7606(1985)96<1518:LCLEOL >2.0.CO;2

[10] Wells, S.G., McFadden, L.D. and Dohrenwend, J.C. (1987) Influence of Late Quaternary Climatic Changes on Geomorphic and Pedogenic Processes on a Desert Piedmont, Eastern Mojave Desert, California. Quaternary Research, 27, 130-146. http://dx.doi.org/10.1016/0033-5894(87)90072-X

[11] McFadden, L.D., McDonald, E.V., Wells, S.G., Anderson, K., Quade, J. and Forman, S.L. (1998) The Vesicular Layer and Carbonate Collars of Desert Soils and Pavements: Formation, Age, and Relation to Climate Change. Geomorphology, 24, 101-145. http://dx.doi.org/10.1016/S0169-555X(97)00095-0

[12] McFadden, L.D., Wells, S.G. and Dohrenwend, J.C. (1986) Influences of Quaternary Climatic Changes on Processes of Soil Development on Desert Loess Deposits of the Cima Volcanic Field, California. Catena, 13, 361-389. http://dx.doi.org/10.1016/0341-8162(86)90010-X

[13] McFadden, L.D., Jercinovich, S.G. and Wells, M.J. (1987) Influences of Aeolian and Pedogenic Processes on the Origin and Evolution of desert Pavements. Geology, 15, 504-508. http://dx.doi.org/10.1130/0091-7613(1987)15<504:IOEAPP>2.0.CO;2

[14] Chadwick, O.A. and Davis, J.O. (1990) Soil-Forming Intervals Caused by Aeolian Sediment Pulses in the Lahontan Basin, Northwestern Nevada. Geology, 18, 243-246. http://dx.doi.org/10.1130/0091-7613(1990)018<0243:SFICBE>2.3.CO;2

[15] McDonald, E.V., Pierson, F.B., Flerchinger, G.N. and McFadden, L.D. (1996) Application of a Soil-Water Balance Model to Evaluate the Influence of Holocene Climate Change on Calcic Soils, Mojave Desert, California, U.S.A. Geoderma, 74, 167-192. http://dx.doi.org/10.1016/S0016-7061(96)00070-5

[16] Belnap, J. and Gillette, D.A. (1998) Vulnerability of Desert Biological Soil Crusts to Wind Erosion: the Influences of Crust Development, Soil Texture, and Disturbance. Journal of Arid Environments, 39, 133-142. http://dx.doi.org/10.1006/jare.1998.0388

[17] Shachak, M. and Lovett, G.M. (1998) Atmospheric Deposition to a Desert Ecosystem and Its Implications for Management. Ecological Applications, 8, 455-463. http://dx.doi.org/10.1890/1051-0761(1998)008[0455:ADTADE]2.0.CO;2

[18] Reynolds, R.L., Belnap, J., Reheis, M., Lamothe, P. and Luiszer, F. (2001) Aeolian Dust in Colorado Plateau Soils: Nutrient Inputs and Recent Change in Source. Proceedings of the National Academy of Sciences, 98, 7123-7127. http://dx.doi.org/10.1073/pnas.121094298

[19] Gurugubelli, B., Pervez, S. and Tiwari, S. (2013) Characterization and Spatiotemporal Variation of Urban Ambient Dust Fallout in Central India. Aerosol and Air Quality Research, 13, 83-96. http://dx.doi.org/10.4209/aaqr.2012.06.0141

[20] Goossens, D. and Buck, B. (2009) Dust Emission by Off-road Driving: Experiments on 17 Arid Soil Types, Nevada, USA. Geomorphology, 107, 118-138. http://dx.doi.org/10.1016/j.geomorph.2008.12.001

[21] Satheesh, S.K. and Moorthy, K.K. (2005) Radioactive Effects of Natural Aerosols: A Review. Atmospheric Environment, 39, 2089-2110. http://dx.doi.org/10.1016/j.atmosenv.2004.12.029

[22] Khalaf, F.I. and Al-Ajmi, D. (1993) Aeolian Processes and Sand Encroachment Problems in Kuwait. Geomorphology, 6, 111-134. http://dx.doi.org/10.1016/0169-555X(93)90042-Z

[23] Halwagy, R. and Halwagy, M. (1974) Ecological Studies on the Desert of Kuwait: II. The Vegetation. Journal of the University of Kuwait (Science), 1, 87-95. 
[24] Halwagy, R., Moustafa, A.F. and Kamel, S.M. (1982) On the Ecology of the Desert Vegetation in Kuwait. Journal of Arid Environments, 5, 95-107.

[25] AI-Awadhi, J.M., Omer, S.A. and Misak, R.F. (2005) Land Degradation Indicators in Kuwait. Journal of Land Degradation and Development, 16, 163-176. http://dx.doi.org/10.1002/ldr.666

[26] Kuwait Institute for Scientific Research (KISR) (1999) Soil Survey for the State of Kuwait. KISR, Kuwait.

[27] Khalaf, F. (1989) Desertification and Aeolian Processes in the Kuwait Desert. Journal of Arid Environments, 16, 125-145.

[28] Omar, S.A. (1991) Dynamics of Range Plants Following 10 Years of Protection in Arid Rangelands of Kuwait. Journal of Arid Environments, 21, 99-111.

[29] Zaman, S. (1997) Effects of Rainfall and Grazing on Vegetation Yield and Cover of Two Arid Rangelands in Kuwait. Environmental Conservation, 24, 344-350. http://dx.doi.org/10.1017/S0376892997000453

[30] Brown, G. and Porembski, S. (1997) The Maintenance of Species Diversity by Miniature Dunes in a Sand-Depleted Haloxylon Salicornicum Community in Kuwait. Journal of Arid Environments, 37, 461-473. http://dx.doi.org/10.1006/jare.1997.0286

[31] Brown, G. and Porembski, S. (1998) Flora and Vegetational Aspects of Miniature Dunes in a Sand-Depleted Haloxylon salicornicum Community in the Kuwait Desert. Flora, 193, 133-140.

[32] Omar, S., Bhat, N.R., Shahid, S. and Assem, A. (2005) Land and Vegetation Degradation in War-Affected Areas in the Sabah Al-Ahmad Nature Reserve of Kuwait: A Case Study of Umm. Ar. Rimam. Journal of Arid Environments, 62, 475-490. http://dx.doi.org/10.1016/j.jaridenv.2005.01.009

[33] Misak, R.F., Al-Awadhi, J.M. and Al-Sudairawi, M. (2001) Assessing and Controlling Land Degradation in Kuwaiti Desert Ecosystem. In: Al-Sarawi, M. and Massoud, M., Eds., The Impact of Environmental Pollution on Development in the Gulf Region, II, Environmental Public Authority, State of Kuwait, 209-223.

[34] Shahid, S.A., Omar, S. and Al-Ghawas, S. (1999) Indicators of Desertification in Kuwait and their Possible Management. Desertification Control Bulletin, 34, 61-66.

[35] Al-Dousari, A.M., Misak, R. and Shahid, S. (2000) Soil Compaction and Sealing in AL-Salmi Area, Western Kuwait. Journal of Land Degradation and Development, 11, 401-418. http://dx.doi.org/10.1002/1099-145X(200009/10)11:5<401::AID-LDR396>3.0.CO;2-4

[36] Al-Awadhi, J.M., Misak, R. and Omer, S. (2003) The Causes and Consequences of Desertification in Kuwait: A Case Study of Land Degradation. Bulletin of Engineering Geology and the Environment, 62, 107-115.

[37] Omar, S.A., Bhat, N.R., Shahid, S.A. and Asem, A. (2006) Land and Vegetation Degradation in War-Affected Areas in the Sabah Al-Ahmad Nature Reserve of Kuwait. European Journal of Scientific Research, 14, 146-158.

[38] Al-Awadhi, J.M. (2008) Mapping Land Degradation Hazard in Kuwait: Using Delphi and AHP Methods. Kuwait Journal of Science and Engineering, 35, 71-91.

[39] Al-Awadhi, J.M. (2013) A Case Assessment of the Mechanisms Involved in Human-Induces Land Degradation in Northeastern Kuwait. Journal of Land Degradation and Development, 24, 2-11. http://dx.doi.org/10.1002/ldr.1090

[40] Al-Awadhi, J.M. (2001) Impact of Gravel Quarrying on the Desert Environment of Kuwait. Environmental Geology, 41, 365-371. http://dx.doi.org/10.1007/s002540100398

[41] Al-Dousari, A.M., Al-Elaj, M., Al-Enezi, E. and Al-Shareeda, A. (2009) Origin and Characteristics of Yardangs in the Um Al-Rimam Depressions (N. Kuwait). Geomorphology, 104, 93-104. http://dx.doi.org/10.1016/j.geomorph.2008.05.010

[42] Al-Awadhi, J.M. (2005) Dust Fallout Characteristics in Kuwait: A Case Study. Kuwait Journal of Science and Engineering, 32, 135-152.

[43] Folk, R.L. (1974) Petrology of Sedimentary Rocks. Hemphill, Texas.

[44] Al-Awadhi, J.M. (1999) Air-Flow Characteristics over Large Rough Surfaces: A Wind-Tunnel Study. Kuwait Journal of Science and Engineering, 26, 355-376.

[45] Yan, Y.C., Xu, X.L., Xin, X.P., Yang, G.X., Wang, X., Yan, R.R. and Chen, B.R. (2011) Effect of Vegetation Coverage on Aeolian Dust Accumulation in a Semiarid Steppe of Northern China. Catena, 87, 351-356. http://dx.doi.org/10.1016/j.catena.2011.07.002 
Scientific Research Publishing (SCIRP) is one of the largest Open Access journal publishers. It is currently publishing more than 200 open access, online, peer-reviewed journals covering a wide range of academic disciplines. SCIRP serves the worldwide academic communities and contributes to the progress and application of science with its publication.

Other selected journals from SCIRP are listed as below. Submit your manuscript to us via either submit@scirp.org or Online Submission Portal.
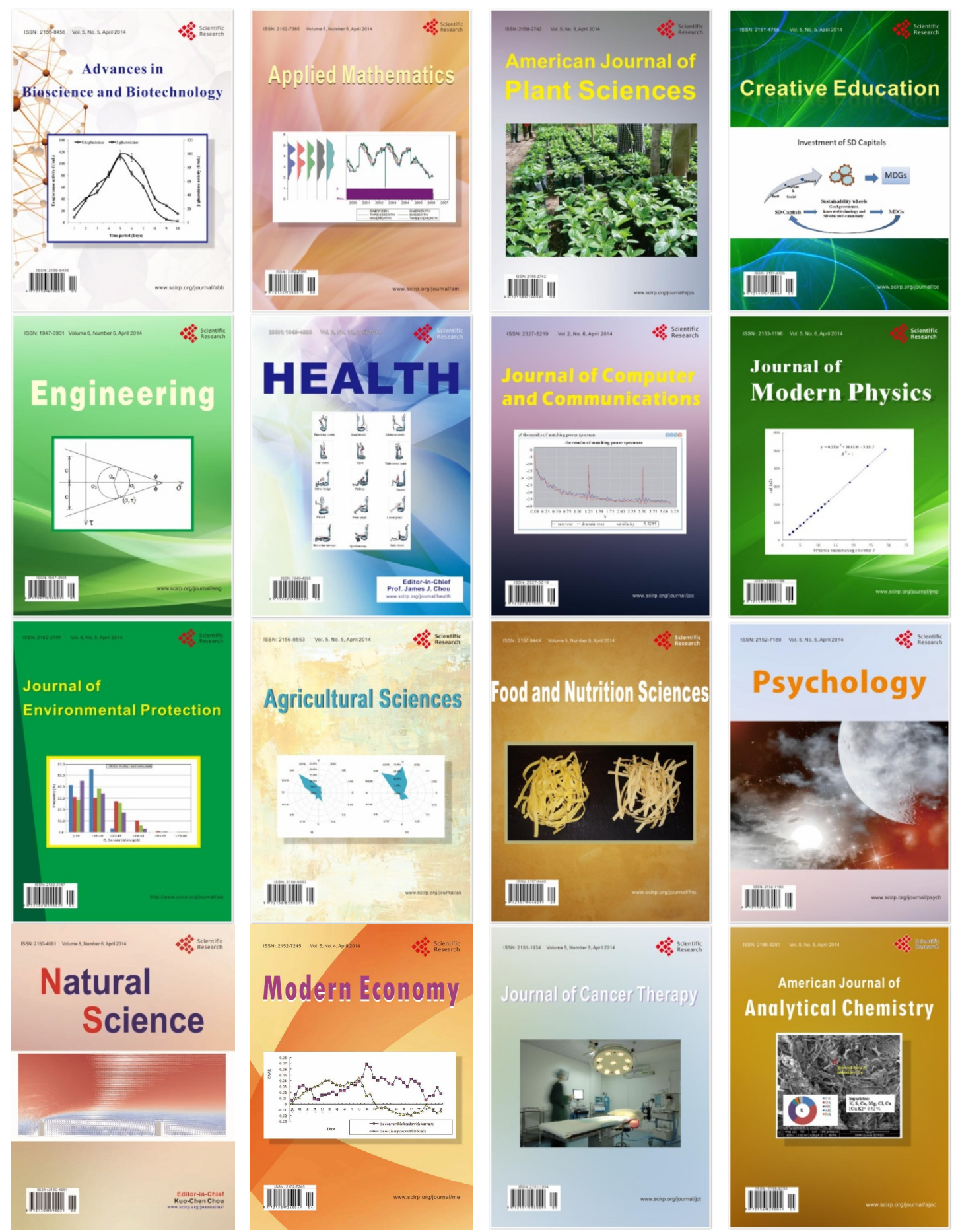